\title{
VÝZNAM PRÁVNÍ TEORIE \\ PRO VÝUKU KANONICKÉHO PRÁVA \\ (SE ZAMĚŘENÍM NA PROBLEMATIKU PRÁVNÍCH PRINCIPŮ)
}

A NTONÍN IGNÁC HRDINA

\section{1. Úvodem}

Wásledující stat ${ }^{1}$ chce předložit několik úvah na téma významu právní teorie pro výuku kanonického práva, a to se zvláštním zaměřením na problematiku právních principů.

Když jsem v roce 1983 v rámci studia práv na pražské právnické fakultě studoval mimo jiné obecnou teorii práva, dostal se mi tehdy do ruky nedávno vyhlášený nový Kodex kanonického práva - ono první zelené vydání z vatikánské Polyglotty. ${ }^{2}$ A já jsem s údivem zjistil, že to, co nám v rámci obecné teorie práva přednášeli jako málem nějakou tajnou kabalistickou nauku, je - mutatis mutandis - tématem první knihy tohoto kodexu, tzv. Všeobecných norem (Normae generales). Jistě, i starý piánsko-benediktinský kodex ${ }^{3}$ vyhlášený v roce 1917 měl - patrně pod vlivem obecné části německého občanského zákoníku ${ }^{4}$ - své všeobecné normy, ty se však s těmi dnešními co do rozsahu nedaly srovnat; ale Všeobecné normy nového kodexu - to je teorie práva v normativní podobě! A to je myšlenka, která mě od té doby provází (nebo spíš pronásleduje) celou mou právnickou i akademickou dráhou: že totiž právo je v zásadě jen

1 Jejím základem je přednáška před Vědeckou radou Cyrilometodějské teologické fakulty Univerzity Palackého v Olomouci, přednesená autorem dne 10. 10. 2007 v rámci jmenovacího řízení.

2 Codex iuris canonici auctoritate Ioannis Pauli PP. II promulgatus, editio prima, Libreria editrice Vaticana M.DCCCC.LXXXIII.

3 Codex iuris canonici Pii X Pontificis Maximi iussu digestus Benedicti Papae XV auctoritate promulgatus praefatione E.mi Petri Card. Gasparri et indice analytico-alphabetico auctus.

4 Bürgerliches Gesetzbuch z roku 1896, který nabyl účinnosti dne 1. 1. 1900; k tomu srov. např. KNAPP, Viktor. Velké právni systémy: (úvod do srovnávací védy). 1. vydání. Praha: C. H. Beck, 1996, s. 130-132. 
jedno - at' světské nebo kanonické ${ }^{5}$ (alespoň ve vnějším oboru), a že toto právo má jen jednu obecnou teorii, která je klíčem k jeho pochopení. A že tedy tuto obecnou teorii je třeba aplikovat jak na právo světské a jeho jednotlivá odvětví, tak také na právo kanonické.

Jenže věc má své úskalí: tyto Všeobecné normy jsou sice teorií kanonického práva, ale nejsou ućebnici teorie kanonického práva; a bez potřebného komentáře nebo učebnice jsou posluchačům kanonického práva jen velmi obtížně př́stupné, už proto, že se - jak z jejich povahy vyplývá - pohybují na značně abstraktní úrovni (nic konkrétního „pro život" se tam čtenář nedoví). A právě to je důvod, proč bývají opomíjeny nejen právními kutily a samouky, nýbrž i studenty a následně těmi, jimž je svěřena i aplikace kanonického práva. Tady se sluší citovat to, co prý ř́kával profesor José Maria Castagno z právnické fakulty Lateránské univerzity v Římě, ${ }^{6}$ že ten, kdo nezná Všeobecné normy, bude v kanonickém právu vždycky jen diletantem. Pokušení obejít teorii práva a vrhnout se př́mo na studium práva platného je ovšem aktuální nejen u posluchačů kanonického, nýbrž i světského práva. Proto můj bývalý učitel a nynější vedoucí katedry právních dějin na plzeňské právnické fakultě profesor Stanislav Balík ve volné návaznosti na sira Waltera Scotta ${ }^{7}$ vždycky svým studentům připomíná, že kdo zná jen platné právo, to je „zedník práva“; stavitel práva musí znát i právní dějiny a právní teorii.

\section{Význam teorie pro studium práva}

Vždyt je to právě právní teorie, která seznamuje se základními právními pojmy a instituty, bez nichž nelze ve většině př́padů do právní problematiky vniknout. Konec konců už samo právo je pojmem víceznačným (polysémem). Není jen teologickou či vůbec pedagogickou disciplínou a vědním oborem, jako většina ostatních předmětů vyučovaných na teologii, jako je dogmatika, biblikum, pastorálka apod.; právem (v objektivním smyslu) se rozumí i souhrn pravidel chování, tedy normativní systém, jehož specifikem je - v krajním případě - možnost vynucení žá-

5 K tomu viz můj článek Kanonické právo $\mathrm{v}$ proměnách času: (leges multae, ius unum). In KNOLL, Vilém (ed.). Pocta Stanislavu Balikovi $k$ 80. narozeninám. Acta historico-iuridica Pilsnensia 2008. 1. vydání. Plzeň: Aleš Čeněk, 2008, s. 120-129.

6

Znalost této hluboce pravdivé teze mi zprostředkoval někdejší Castagnův žák, absolvent právnické fakulty Lateránské univerzity a nynější místopředseda pražského církevního soudu ThDr. Jiří Svoboda, I.C.D.

„A lawyer without history is a mechanic, a mere working mason; if he possesses some knowledge of these, he may venture to call himself an architect" (historický román Waltera Scotta Guy Mannering z roku 1815). 
doucího chování veřejnou mocí - státní nebo církevní; je tedy profilujícím regulátorem lidského chování. Právem (v subjektivním smyslu) se pak rozumí oprávnění, tj. objektivním právem stanovená míra dovoleného či přikázaného chování. Právo je ale v dikci Starého zákona také mnohdy synonymem pro spravedlnost a tvoří spolu s ní jakousi párovou kategorii (ius et iustitia). Právo v sociologickém pojetí je významným instrumentem k řízení a ovládání lidské společnosti. A tak by bylo možno pokračovat a jít až k samé podstatě pojmu práva a jeho místa v lidské kultuře, a na to byly v lidských dějinách různé názory: od chronologicky nejstaršího jusnaturalismu, který je charakteristický i pro křestanskou filosofii práva, přes právní pozitivismus 19. století a neopozitivistické směry 20. století až po recentní sociologizující a psychologizující směry - to vše v nesčetných odstínech a variacích.

Ale neméně důležité než vědět, co právo je, je důležité vědět, jak ve společnosti (at' občanské nebo církevní) působí, tedy umět si představit mechanismus fungování práva; že dochází k interakci a vzájemné penetraci obou normativních systémů - práva světského i kanonického. Věc se přece nemá tak, že věřící občan se od pondělka do pátku (a přes den a v práci) řídí právem světským, zatímco o sobotách a nedělích (a večer a v kostele) se spravuje právem kanonickým: toto „obojí právo“ (ius utrumque) působí na věřícího jako jediný normativní tok impulsů motivujících, popř. i determinujících jeho chování, a to ještě tyto impulsy většinou pocházejí ze zdrojů neprávní povahy (z hromadných sdělovacích prostředků, z kázání, z rozhovorů s ostatními lidmi apod.); a to už je otázka po formálních pramenech práva. Jakousi „molekulárni“ jednotkou tohoto práva jsou právní normy jakožto veřejnou mocí sankcionovaná pravidla chování. Často je ovšem třeba tyto normy vykládat, aby se dospělo k jejich správnému významu (ratio legis) - to je věcí interpretace práva. Mají-li však tyto normy plnit svou funkci, musí tvořit určitý logický a logicky bezrozporný celek - to je otázka po systému práva. Ne vždy se ovšem právní norma uskutečňuje (realizuje) svou pouhou existencí, jako je tomu např. u norem stanovících bezpodmínečným (ahypotetickým) způsobem základní práva člověka $\mathrm{v}$ občanské společnosti, resp. křestana $\mathrm{v}$ církvi. Mnohdy práva a povinnosti předvídané v právních normách vznikají teprve po přistoupení určité, z hlediska práva významné skutečnosti, s níž právo spojuje svou dynamiku, tedy v rámci právních vztahů nebo v procesu úřední aplikace práva. A protože i křestané jsou lidé, kteří nejenom hřeší, ale chovají se i protiprávně, realizuje se i kanonické právo také v rámci odpovědnostních právních vztahů - v krajním případě i vztahů trestněprávních. 
Toto právo však nefunguje $\mathrm{v}$ nějakém společenském vakuu, nýbrž v konkrétním sociálním prostředí. Má-li v něm tedy působit co nejúčinněji - a to je otázka po efektivnosti práva -, musí se teorie práva vypořádat s řadou souvisejících otázek, které jsou na hranici obecné právní teorie, filosofie práva a tzv. sdružených právních disciplín, jako je problém stability a dynamiky práva, právní jistoty, důvěry v právo a právního vědomí adresátů práva apod. Jednu z těchto otázek představuje také problematika právních principů a jejich správného použití při tvorbě a aplikaci práva.

\section{O právních principech obecnè}

Výuka práva - světského i kanonického - má za cíl nejen seznámit posluchače $s$ př́slušným právním řádem, nýbrž také je naučit s tímto právem zacházet. A toto zacházení spočívá nejčastěji v tzv. aplikaci práva, tedy v určitém právem stanoveném postupu, v němž orgán veřejné moci (státní nebo církevní, soudní nebo správní) aplikuje obecnou normu práva na jedinečnou a konkrétní situaci (nebo, jinak řečeno, subsumuje skutkovou podstatu faktickou pod skutkovou podstatu právní). Výsledkem je akt aplikace práva neboli individuální právní akt, který bud' nově stanoví (vytvoř́, konstituje) práva a povinnosti subjektů př́slušného právního vztahu (to jsou tzv. konstitutivní právní akty), anebo autoritativně konstatuje čili deklaruje určitou právní situaci (to jsou tzv. deklaratorní právní akty).

Může se ale stát, že v právně relevantní situaci neexistuje žádná právní norma, která by danou věc upravovala, ba ani norma, která by upravovala případ podobný, takže orgán aplikující právo (typicky soudce) nemůže postupovat ani per analogiam legis. Přitom však nemůže stranám říct: „Jděte domů, já na to nemám žádný paragraf nebo kánon“ - to by bylo odepření spravedlnosti (denegatio iustitiae). On věc musí rozhodnout ale podle čeho? Tady se objevuje otázka po možných tzv. mezerách v právu (lacunae iuris). Z formálně logického hlediska vlastně žádná mezera v právu neexistuje. Právní norma jakožto součást hodnotícího systému, jímž právo je, dává odpověd' na otázku po dovolenosti (liceitě) lidského chování, a tato odpověd má binární povahu (nebo, chceme-li, vyjadřuje se toliko ve dvou modalitách): některé chování je podle právní normy bud' dovoleno (třeba i implicitně tím, že je přikázáno), anebo dovoleno není (tedy je zakázáno). Tertium non datur - žádná sféra práva prostá neexistuje, tak jakápak mezera v právu. ${ }^{8}$

8 K tomu srov. KNAPP, Viktor. Teorie práva. 1. vydání. Praha: C. H. Beck, 1995, s. 65-67. 
Jenže otázka, kterou soudce musí rozhodnout, nemusí vždycky znít jen po dovolenosti chování; a právě v takových př́padech, není-li k dispozici odpovídající norma, se soudce skutečně setkává s mezerou - spíše však v zákoně než v právu. A pak je ovšem nucen poohližet se po jiných pramenech práva, než je na evropském kontinentě zákon (popř. precedent v právní oblasti angloamerické).

U nás, $\mathrm{v}$ českém právu, je řešení této problematiky ponecháno teorii práva. Ta mluví o postupu „per analogiam iuris“ (podle analogie práva), čímž jsou ovšem míněna rozhodnutí podle obecných právních zásad. Ve skutečnosti se tedy o žádnou analogii nejedná, protože zde žádné analogon neexistuje. Jde o rozhodnutí podle rozumného uvážení soudce, který už nikoli „nalézá“ právo (ius dicit inter partes), jak je tomu zásadně v evropské kontinentální právní kultuře, nýbrž toto právo ve skutečnosti dotváří či dokonce nově tvoří (ius facit inter partes), jak je to obvyklé v angloamerické právní oblasti. Že je zde ponechán značný prostor pro uvážení orgánu aplikujícímu právo, je téměř nadbytečné dodávat: soudce už není pouhými „ústy zákona“, nýbrž tvůrcem absentujícího pravidla chování (tedy normy) pro jednotlivý případ.

V kanonickém právu naproti tomu existuje v kánonu 19 Kodexu kanonického práva explicitní ustanovení, podle nějž chybí-li v některém případě výslovné ustanovení zákona (a nejde přitom o věc trestní), má se záležitost rozhodnout mj. podle obecných právních zásad (secundum generalia iuris principia) při zachování kanonické umírněnosti.

Tyto obecné právní zásady jsou jakési vůdčí ideje, uznávané obecně (tj. většinou nebo dokonce všemi civilizovanými právními řády) a prostupující jednotlivá právní odvětví nebo (u těch nejobecnějších) dokonce právní řád jako takový, a to jak př̀i tvorbě právních předpisů, tak také zejména při jejich aplikaci. Jsou výsledkem mnohasetleté právnické zkušenosti, staletou vymožeností právní kultury. Netvoří žádný ucelený (či dokonce logicky konsistentní) systém. Zásadně nejsou součástí právního řádu v pozitivistickém chápání práva, tj. nemají (resp. nemusejí mít) normativní podobu; tak např. princip, který stanoví, že pozdější zákon zrušuje zákon dřívější (lex posterior derogat legi priori) v českém právu. ${ }^{9}$ Pokud tomu tak je (jako je tomu u tohoto principu v kanonickém právu), stávají se právními normami sui generis a platí pro ně režim stanovený pro právní normy. Některé jsou odvozeny z božského práva, at pozitivního či přirozeného (např. princip rovnosti před zákonem - ita parvum

9 Naproti tomu v kanonickém právu má tento princip formu právní normy, viz kán. 20 CIC; stejně kán. 1502 \$ CCEO. 
audietis ut magnum, princip práva na obhajobu, princip povinného slyšení druhé strany - audiatur et altera pars, princip nutnosti dodržování smluv - pacta sunt servanda apod.); některé naproti tomu představují ius humanum, popř. - v kanonickém právu - ius mere ecclesiasticum.

Tyto obecné právní zásady ovšem nejen suplují absentující právní úpravu, jak bylo výše ukázáno, ale také doplňují již existující a slouží její interpretaci. Ty nejvýznamnější představují dokonce určitý korektiv obsahu právních norem. Zatímco však právní norma se aplikuje podle schématu „všechno nebo nic“ (tzn. právní norma se na daný případ bud' vztahuje nebo nevztahuje), mohou být v téže právní situaci k dispozici dva rozdílné (až kontradiktorní) principy, jejichž použitelnost pak musí aplikující orgán zvažovat. A to je nutné zejména v těch (spíše výjimečných) obtížných případech ( hard cases), kdy je podle právního vědomí a svědomí soudce třeba dát přednost právnímu principu dokonce před jasnou normou pozitivního práva. Tady bych chtěl pro ilustraci připomenout slavný rozsudek newyorského soudu v prŕpadu Riggs v. Palmer z roku 1889, který řešil otázku, zda dědic, uvedený v závěti svého dědečka, může na základě této závěti dědit, třebaže kvůli tomu, aby dědil, svého dědečka zabil. Do konfliktu se zde dostala jasná a jednoznačná norma dědického práva, podporovaná navíc principem právní jistoty, a další (alespoň v USA) obecně uznávaná zásada, že se nikomu nesmí dovolit, aby měl prospěch ze svého protiprávního jednání; a s odvoláním na tento posledně jmenovaný princip soud vrahovi dědictví upřel. Možná nám to připomíná už římskoprávní zásadu: $E x$ iniuria ius non oritur. Už z toho je patrné, že zatímco právní norma může být hodnotově (axiologicky) neutrální, právní principy jsou zpravidla nositeli určitých hodnot v právu, jako je spravedlnost, lidská svoboda a právní jistota. Pro kanonické právo jsou charakteristické dva principy: princip kanonické umírněnosti (aequitas canonica) a princip vyjádřený floskulí Suprema lex salus animarum (tato „salus animarum“ je analogickou hodnotou jako „salus rei publicae“ či „salus populi“v právu světském). ${ }^{10}$

\section{O právních principech v kanonickém právu}

Jinak ale, pokud jde o právní principy v kanonickém právu, odkazují komentáře ke kodexu většinou na 88 regulí iuris, ${ }^{11}$ připojených za středověkou sbírku dekretálů, pořízenou roku 1298 papežem Bonifácem VIII. a zná-

10 Patrně podle Ciceronova díla De legibus $(3,3,8)$ : „Salus populi suprema lex esto.“

11 Jejich latinský text spolu s překladem do češtiny uvádí HRDINA, Antonín. Prameny ke studiu kanonického práva. 1. vydání. Plzeň: Aleš Čeněk, 2007, s. 63-69. 
mou obvykle pod jménem Liber sextus. ${ }^{12}$ Bonifác, sám vynikající právník, se inspiroval kodifikačním dílem svého předchůdce papeže Řehoře IX., který za monumentální sbírku dekretálů, ${ }^{13}$ pořízenou roku 1234 jeho kaplanem Raymundem z Penayfortu, připojil také 11 právních pravidel. Těch 88 regulí iuris, které pro účely Bonifácovy kodifikace sestavil boloňský právník Dinus Mugellanus, nejsou sbírkou po obsahové stránce př́liš originální; jsou (mírně řečeno) inspirovány římským právem, zejména justiniánskou kodifikací (některé zásady jsou z Digest převzaty doslova). Nicméně jejich sbírka je obohacena o principy ovládající výlučně právo kanonické.

Že se při výkonu spravedlnosti vždycky nevystačí s pozitivním právem, to zjistili Římané ještě za republiky. Bývá tomu tak zejména tehdy, když právní úprava př́liš zaostává za společenskými poměry, jako tomu bylo v době, kdy pro expandující římské impérium platily komiciální zákony z doby, kdy Řím byl ještě větší vesnicí. Proto prétor, ačkoli formálně byl „služebník zákonů“ (minister legum), rozhodoval ne vždy podle stále více zastarávajícího civilního práva, nýbrž také podle vlastního právního uvážení s přihlédnutím k vyšší spravedlnosti, již Římané nazývali ekvitou (aequitas). Mohl si to dovolit pro svou výjimečnou pravomoc, které se těšil (tzv. imperium). Vedle práva občanského (ius civile) tak vznikala další masa práva - práva prétorského neboli honorárního. Prakticky stejná situace nastala o více než tisíc let později v Anglii, kdy nejprve lord kancléř jménem krále a později kancléřské soudy rozhodovaly nové záležitosti ne podle petrifikovaného obecného práva, které na takové př́ípady mnohdy ani nepamatovalo, nýbrž podle spravedlivého uvážení kancléřského soudu, takže i tam se vedle „obecného práva“ (Common Law) rodila další masa práva, zvaná jak jinak než Equity.

Lze se tedy ptát: je-li tomu tak, v čem spočívalo novum kodifikace právních principů v Knize Šesté Bonifáce VIII.? Nepochybně v tom, že obsahová kvalita zákona se při jeho aplikaci nemusela nadále konfrontovat s tak vágními pojmy, jako je ekvita, spravedlnost, přirozené právo atd., že soudce už nebyl odkázán jen na své právní cítění, nýbrž že měl k dispozici celou škálu relativně konkrétních pravidel, která mu umožňovala vyhnout se formalismu při aplikaci právních norem, který tolik zatěžoval tehdejší právní myšlení (později to bude patrné zvláště v germánském a slovanském právu). Některé $\mathrm{z}$ těchto principů jsou platné doposud, jiné byly právním vývojem překonány. Ale dodnes svědčí o tom, že církev dávno před vznikem moderních právních škol věděla, že právo není

12 Úřední název: Liber Sextus decretalium Domini Bonifatii Papae VIII.

13 Tzv. Liber extra; úřední název: Decretalium D. Gregorii Papae IX compilatio. 
totožné se zákonem a že zákon - aby byl současně právem - musí být interpretován a aplikován se zřetelem k určitým zásadám pramenícím namnoze z práva přirozeného (nebo chceme-li, zde na teologické fakultě je jistě na místě to zvlášt připomenout, z práva božského). To je jeden z největších přínosů kanonické jurisprudence pro moderní právní vědu, která problematiku právních principů znovuobjevila vlastně až v poslední čtvrtině dvacátého století (tady mám na mysli zejména „zlomové“ dílo Ronalda M. Dworkina z Oxfordu A Matter of Principle z roku 1986). ${ }^{14}$

To, co bylo řečeno, samozřejmě nevylučuje aplikaci právních principů, obvykle užívaných ve světském právu, také v právu kanonickém, přirozeně nakolik tyto neodporují právu božskému (což s ohledem na jejich povahu asi jen zřídka připadá v úvahu). Jde např. o zásady „Ubi ius incertum, ibi ius nullum“, „In dubio pro reo“, „In dubio mitius“, „Ne bis in idem“apod. ${ }^{15}$

\section{Závěrem}

Jistěže aplikace práva s použitím obecných právních principů patří k odborně nejnáročnějším úkolům těch nositelů veřejné moci (at́ státní nebo církevní), jimž je aplikace práva svěřena, už proto, že klade vysoké nároky na jejich právní cítění, právnické vzdělání a na moudrost při aplikaci práva za použití vysoké míry vlastního uvážení.

Také absolventi teologických fakult (alespoň ti, kteří zůstanou „v oboru“), budou mít aplikaci práva jaksi ve své pracovní náplni: at už spíše okrajově, jako je tomu u farářů, nebo jako jednu z hlavních činností, jako je tomu u ordinářủ, nebo dokonce jako své výlučné povolání, jako je tomu (po získání gradu z kanonického práva) u církevních soudců, obhájců manželského svazku a promotorů iustitiae. Ti všichni by měli napomáhat právu a spravedlnosti - těmto Božím darům lidstvu. Je třeba si přát, aby to činili kvalifikovaně a moudře; aby mezi nimi bylo co nejméně „zedníků práva“. Důsledná výuka právní teorie může toto pium desiderium pomoci vyplnit.

Antonín Ignác Hrdina (1953), Katedra pastorálních oborů a právních véd KTF UK

14 Kniha dosud nebyla přeložena do češtiny.

15 Řada kanonických právních principů včetně jejich překladu do češtiny je obsažena v knize HRDINA, Antonín. Kanonické právo. 1. vydání. Praha: EUROLEX Bohemia, 2002, s. 408-418; přehled vybraných právních principů funkčních dodnes v právu světském je uveden např. v publikaci GERLOCH, Aleš. Teorie práva. 1. vydání. Dobrá Voda: Aleš Čeněk, 2000, s. 210. 


\begin{abstract}
ANTONÍN IGNÁC HRDINA

The Significance of the Theory of Law

for Teaching the Canon Law

(with Special Attention to Problems of the Principles of Law)
\end{abstract}

Also the canon law in teaching and all the more in its application needs the general theory of law. The principles of law have a special importance here; they partly complement, partly penetrate the positive law and are serving for an equitable application of the law in "hard cases".

Key words

canon law, general theory of law, principles of law 